\title{
Damping Resistances in Rolling, Pitching, and Vibration of a Ship in her Motion-ahead.
}

\author{
By Katsutada Sezawa, KH., RH., Member, \\ Tokyo Imperial University ${ }^{(1)}$.
}

\begin{abstract}
.
In his previous paper, the author obtained the coefficient of vibration damping of a plate that is parallel to a water stream, and movable normal to the same stream, with a theory regarding the dynamic damping of the vibrations of a ship in motionahead. Although the vibration damping of any ship increases almost linearly with speed, since the vibrational force usually varies as the square of the same speed, the amplitudes of the ship vibrations are apparently augmented with speed increase. Since, however, no data on vibration test of an actual ship was given in the previous paper, there has remained some doubt as to whether or not the damping condition in a full-sized ship would obey the law that the author formulated.

In the present paper, with a view to confirming the results given in the previous paper, the author directs his attention to the results of the rolling experiments of the "Revenge" that was conducted about fifty years ago. Based on the data of his model experiments with a plate vibrating in a circulation water tank that were published in his previous paper and also reexamined in this one, he predicted the damping coefficient of the rolling of H.M.S. "Revenge" in her motion-ahead (free of the actual coefficient of the vessel itself), from which he finds that, notwithstanding the large differences between the conditions of the vibrating model plate and the conditions that attended the rolling experiments of the "Revenge," in oscillatory frequency as well as in displacement amplitude, the damping coefficient of rolling of the "Revenge" predicted from the data if model experiments fairly agrees with the same coefficient that hat been actually observed. The author thus concluded that the data of his model experiments can straightway be applied to the vibrations of a full-sized ship-a ship with the frequencies and amplitudes within the range of those model plates in the author's experiments. In extending his investigation to the case of the pitching motion of a ship, the reason for the pitching of a ship in her motion-ahead in a calm sea being damped more quickly than in her stand-still condition was ascertained. Since, as a matter of fact, the problem is merely qualitative, it was impossible for the author to give accurate values of the dynamic damping coefficients under consideration.
\end{abstract}

(1) Upon the author's appointmont by the government, in 1925, to engage in researches in seismology (ant aeronautics), he foun 1 it impossible to interest himself in naval engineering to the exten that he would have liked to have done, with the result that the present paper, together with others the has recently published, on naval engineering, represent merely work that was done in his leisure in the way of recreation as also to repay his scientific debt to naval engineering, in which subject he once held a teaching post. For this reason he hopes that the reader will appreciate the circumstances under which these papers were written and consider mainly the essentials of the papers. 


\section{Introduction.}

In the previous paper ${ }^{(2)}$, it was shown that the vibration damping of a ship increases with increase in speed of her motion-ahead, for which purpose a circulation water tank was used and the change in the coefficient of that vibration damping with speed was qualitatively ascertained. Upon reading the finished paper, the question arose whether or not in an actual ship, the vibration damping could really increase with increase in the speed of the vessel. Although the vibration amplitude of any ship may increase, apparently, with speed increase, sinee the vibrational force usually varies as the square of the spsed, it is impossible to conclude that the vibration damping cannot increase with speed. Since the vibration damping that we have ascertained, increases almost linearly with spoed, such a change in the vibration amplitude as is slower than the square of the ship's speed, is nothing more than an indication of the real existence of the vibration damping in question.

In the previous papər, it was stated that, since the condition that the vibration damping increases with the ship's speed is, as a matter of fact, well established, even though the Reynolds number is not the same, the vibration damping of an actual ship, as predicted from the result of our model experiments, does not differ much from real vibration damping, not at any rate in the order of magnitude. Since, however, there is no experimental data obtained specially for showing the vibration damping of a ship in her motion-ahead, it was not possible to examine and say to what case the problem could be extended. In the previous paper hope was expressed of extending the idea of the present vibration damping to the rolling and pitching of a ship in her motion-ahead, when Dr. Oota kindly called my attention to a paper ${ }^{(3)}$ of John's dealing with a similar problem. In examining that paper, it was a pleasure to find that White's result ${ }^{(4)}$ from the "Revenge" experiments could be applied directly to our investigation. Using the damping coefficientt deduced from the data of our model experiments, without regard to Reynolds number and other dynamical conditions, it was nevertheless possible to ascertain thas the increase of damping in rolling of the "Revenge" in her motion-ahead originated,

(2) K. Sezawa and W. Watanabe, "The Vibration Damping of a Ship in her Moving State," Journ. Soc. Nav. Arch., Japan, 63, (1938), 156-170.

(3) A.W. Johns, "The Effect of Motion ahead on the Rolling of Ships," T.I.N.A., 47 (1905), $186-198$.

(4) Sir W. White, "Notes on Further Experiments with First-class Battleships," T.I.N.A., 36 (1895), 127-150. 
at least qualitatively, from the same cause as that in the vibration damping shown previously, from which there is the likelihood that our previous result is not only available for estimating the vibration damping of a full sized ship, but also could be cxtended to that of the case of rolling or pitching of the same ship.

\section{Experimental Data for the Damping Cuefficient.}

From the vibration experiments with a rectangular plate, $40 \mathrm{~cm}$ long and $20 \mathrm{~cm}$ wide ${ }^{(5)}$, placed lengthwise in a circulation water tank, we obtained the damping force ${ }^{(6)}$

$$
\left\{\left|k_{0}\right|+\left|k_{1}\right| V\right\} \dot{z}
$$

acting per unit area of a plate vibrating with velocity $\dot{z}$ normal to the direction of the stream, $V$ being the velocity of that stream. If $V, \dot{z}$ be taken in $\mathrm{cm} / \mathrm{sec}$, the values of $\left|k_{0}\right|,\left|k_{1}\right|$ are

$$
\left|k_{0}\right|=8.35 \mathrm{gr} . \mathrm{mass} / \mathrm{cm}^{2} \text {. sec, }\left|k_{1}\right|=0.358 \mathrm{gr} . \mathrm{mass} / \mathrm{cm}^{3},
$$

respectively. The damping coefficient $\left|k_{0}\right|$ is not a dynamical coefficient, and the above value of $\left|k_{0}\right|$ depends particularly on the model condition of our previous experiments, while $\left|k_{1}\right|$, on the other hand, participates in the dynamic damping in every case. Since, in the case of an actual ship, there are such dampings as are caused by water friction, generation of pressure waves, generation of surface waves, and structural damping force; the static damping, that is, the damping that is present even in the case of a ship at anchor, should be considered separately ${ }^{(8)}$.

Although in the previous paper, we predicted vibration damping of an actual ship in her motion-ahead, yet for comparing its order of magnitude with that in any other case, the problem in question will now be briefly reviewed. When a ship of the form of parallelopiped is in flexural vibration, the equation of vibration of any cross section is

$$
\rho A \frac{d^{2} T}{d t^{2}}+b\left|k_{1}\right| V \frac{d T}{d t}+n^{2} T=0,
$$

where $n^{2}=m^{4} E I$, the damping coefficient $K_{1}$ being $b\left|k_{1}\right| V / \rho A$. Since $\rho A / b$ is the

(5) This relatively long plate was used for avoiding, as much as possible, the effect of trailing edge on the damping force.

(6) loc. cit. (2).

(7) There were small errors in the numerical calculation in the previous paper, though their effects on the vibration problem are very slight, qualitatively speaking.

(8) K. Sezawa and W. Watanabe, “Damping Forces in Vibrations of a Ship," Journ. Soc. Nav. Arch., Japan, 591 (936), 99-120. 
ship's mass, including the inertia mass of water, per unit area of the ship's bottom, $\left|k_{1}\right| V \dot{z}$ just corresponds to the damping force acting per unit area of the same bottom. Using the value of $\left|k_{1}\right|$ shown already, the dynamic damping coefficient $K_{1}$ at different speeds assumes the following values

$\begin{array}{lllll}\text { Speed of the ship } & V_{1}((\mathrm{~km} / \mathrm{h})=0 & 3 \cdot 6 & 18 & 36 \\ \text { Damping coefficient } & K_{1}\left(\mathrm{sec}^{-1}\right)=0 & 0.0179 & 0.0896 & 0.179\end{array}$

J. Lockwood Taylor's experimental result ${ }^{(9)}$ shows that the damping of a certain ship in still water obeyed the law $e^{-0.066 t}$, that is to say, $K_{1}=0.066\left(\mathrm{sec}^{-1}\right)$, from which it is possible to conclude that vibration damping in still water is of the same order of magnitude as that of dynamic damping with a ship's speed of 6 or 7 knots.

As already shown in the previous paper, the value of the coefficient of dynamic damping $\left|k_{1}\right|$ was determined for a low water velocity range, and furthermore for the case of a relatively small plate. But, if change in dynamic damping with Reynolds number were to obey such a law as that resembling the change in frictional resistance with the same Reynolds number, it would then be possible for model experiments to apply to the case of a full-scale ship, at any rate in the qualitative sense. Since, as a matter of fact, the water velocity in our model experiments was by no means exceptionally low compared with the speed of an actual ship, it is likely that our experimental value could be extended to other cases. It should however be borne in mind that the vibration damping in our case, is not of the kind as frictional resistance of the ship's hull in her steady motion, but results from the momentum imparted by the relative motion of the hull normal to a uniform stream.

\section{Further Experiments for Ascertaining the Effect of the Inertia Mass of Water on the Damping Coefficient.}

Although in the previous paper the existence of the inertia mass of water vibrating with the model was examined, since the relation between the quantity of inertia mass and the dynamic damping of the same model has not yet been ascertained, the following additional experiments were made with the kind assistance of Messrs. W. Watanabe and Z. Yamada.

The same model as that used in the previous study was immersed to a depth of $20 \mathrm{~cm}$ from the free surface of the circulation water tank. The distance $d$ of this plate from the bottom of the tank was $16 \mathrm{~cm}$ in one case and $10.7 \mathrm{~cm}$ in the

(9) J. L.ockwool Tay'or, T.I.N.A., 70 (1930), 162-196. 
other. The methods of experiments were virtually similar to that described in the previous paper.

In every case, experiments in both free and forced vibrations were made for different water velocities, namely, $V=0,0.50 \mathrm{~m} / \mathrm{s}, 0.80 \mathrm{~m} / \mathrm{s}, 1.18 \mathrm{~m} / \mathrm{s}$, respectively, in the first case $(d=16 \mathrm{~cm})$ and $0,0.50 \mathrm{~m} / \mathrm{s}, 0.80 \mathrm{~m} / \mathrm{s}, 1.00 \mathrm{~m} / \mathrm{s}$, respectively, in the second $(d=10.7 \mathrm{~cm})$. The results of observation for forced vibrations in the two cases are shown in Figs. 1, 2. If $\theta$ is the amplitude of oscillation, $N$ the vibrational frequency of the coil, $f$ the maximum force due the current in the same coil, $N_{0}$ the resonance frequency of the mechanical system under experiment, $C$ a constant, and $K$ the damping coefficient of the same system, then the formula for estimating the damping coefficients of the vibration is expressed by

$$
\theta=\frac{f \cos \left\{2 \pi N t-\tan ^{-1} N K / 2 \pi\left(N_{0}^{2}-N^{2}\right)\right\}}{\left.C\left\{N_{0}^{2}-N^{2}\right)^{2}+N^{2} K^{2} / 4 \pi^{2}\right\}^{\frac{1}{2}}} .
$$

Analysing the results in Figs. 1, 2 by means of (4), we get

(i) $K\left(\mathrm{sec}^{-1}\right)=0.81+0.026 \mathrm{~V}(\mathrm{~cm} / \mathrm{sec})$ for the case $d=16 \mathrm{~cm}$,

(ii) $K\left(\mathrm{sec}^{-1}\right)=0.82+0 \cdot 023 V(\mathrm{~cm} / \mathrm{sec})$ for the case $d=10 \cdot 7 \mathrm{~cm}$.

On the other hand, from the results of free vibration experiment, we get

(i) $K\left(\mathrm{sec}^{-1}\right)=1 \cdot 00+0.0250 \mathrm{~V}(\mathrm{~cm} / \mathrm{sec})$ for the case $d=16 \mathrm{~cm}$,

(ii) $K\left(\mathrm{sec}^{-1}\right)=1 \cdot 02+0.0246 \mathrm{~V}(\mathrm{~cm} / \mathrm{sec})$ for the case $d=10 \cdot 7 \mathrm{~cm}$.

The part corresponding to the free vibration in the equation of motion is

$$
\left(I_{0}+I^{\prime}\right) \ddot{\theta}+\left(k_{0}+k_{1} V\right) \dot{\theta}+c_{0} \theta=0,
$$

from which the damping coefficient of the model system becomes

$$
K=\left(k_{0}+k_{1} V\right) / 2\left(I_{0}+I^{\prime}\right) .
$$

Since in the present case $c_{0}=46.8 \cdot 69.10^{7} \mathrm{dyne}-\mathrm{cm} / \mathrm{rad}$. rotation and $N_{0}=4 \cdot 1 / \mathrm{sec}$ (nearly), we get

$$
I_{0}+I^{\prime}=c_{0} /\left(2 \pi N_{0}\right)^{2}=6 \cdot 09.10^{6} \text { gr.mass. } \mathrm{cm}^{2},
$$

from which we have

(i) For the free vibration in case $d=16 \mathrm{~cm}$,

$$
k_{0}=12 \cdot 18.10^{6} \text { gr. mass. } \mathrm{cm}^{2} / \mathrm{sec}, \quad k_{1}=3 \cdot 06.10^{5} \text { gr.mass. } \mathrm{cm} \text {, }
$$

and for the forced vibration in the same case

$$
k_{0}=9 \cdot 85.10^{6} \text { gr. mass. } \mathrm{cm}^{2} / \mathrm{sec}, \quad k_{1}=3 \cdot 17.10^{5} \mathrm{gr} . \text { mass. } \mathrm{cm} \text {; }
$$

(ii) For the free vibration in case $d=10.7 \mathrm{~cm}$,

$$
k=12 \cdot 4.10^{6} \text { gr.mass. } \mathrm{cm}^{2} / \text { sec., } \quad k_{1}=3 \cdot 00.10^{5} \text { gr.mass. } \mathrm{cm} \text {, }
$$

and for the forced vibration in the same case

$$
k_{0}=9 \cdot 97.10^{6} \text { gr.mass. } \mathrm{cm}^{2} / \mathrm{sec}, \quad k_{1}=2 \cdot 80.10^{5} \text { gr. mass. } \mathrm{cm} \text {. }
$$




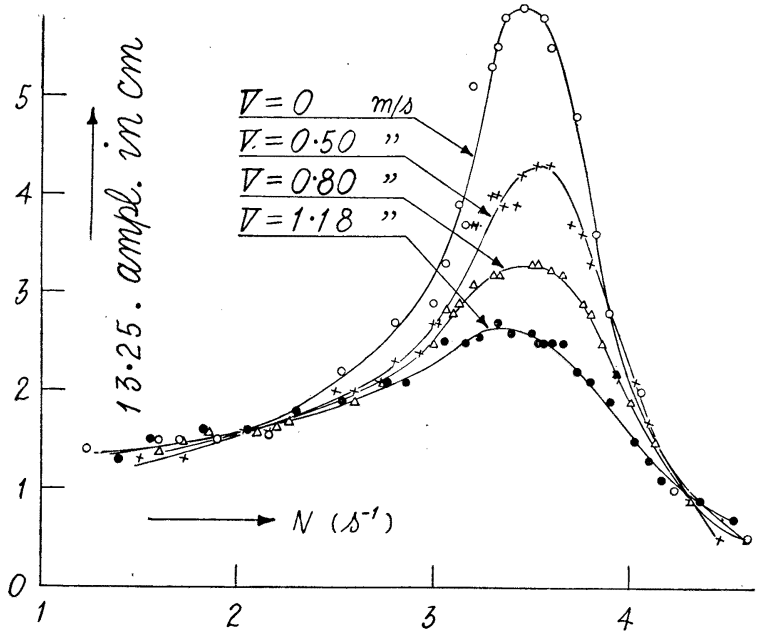

Fig. 1. Resonance Curves for the Case that the Distance $d$ of the Plate from the Bottom of the Tank is $16 \mathrm{~cm}$.

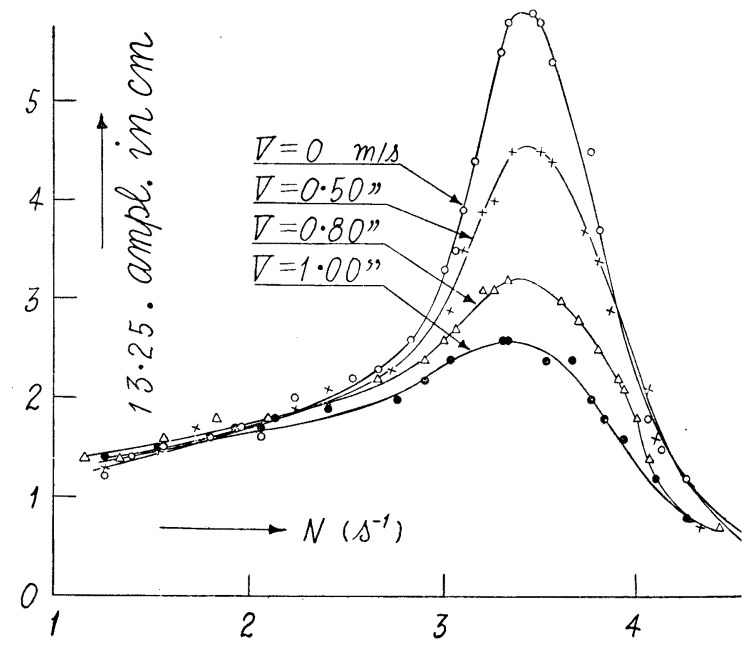

Fig. 2. Kesonance Curves for the Case that the Distance $d$ of the Plate from the Bottom of the Tank is $10.7 \mathrm{~cm}$.

In order to obtain the values of the crefficients of dynamic damping $\left|k_{0}\right|,\left|k_{1}\right|$, we use the relations

$$
\left|k_{0}\right|=3 k_{0} / 2 b L^{3}, \quad\left|k_{1}\right|=3 k_{1} / 2 b L^{3} .
$$

Substituting the values of $k_{0}, k_{1}$ (the respective mean values of $k_{n}, k_{1}$ obtained from free vibration and those obtained from forced vibration) in the relations (7) and putting $b=20 \mathrm{~cm}, L=40 \mathrm{~cm}$, we get the following results.

(i) When the distance between the plate and the bottom of the tank is $d=$ $16 \mathrm{~cm}$,

$$
\left|k_{0}\right|=12.9 \mathrm{gr} . \mathrm{mass} / \mathrm{cm}^{2} \text {. sec, }\left|k_{1}\right|=0.362 \mathrm{gr} \cdot \mathrm{mass} / \mathrm{cm}^{3} .
$$

(ii) When the same distance is $d=10 \cdot 7 \mathrm{~cm}$,

$$
\left|k_{0}\right|=13.09 \mathrm{gr} . \mathrm{mass} / \mathrm{cm}^{2} \text {. sec, }\left|k_{1}\right|=0.339 \mathrm{gr} . \mathrm{mass} / \mathrm{cm}^{3} \text {. }
$$

From these results it will be seen that even should the condition of the inertia mass of the water be considerably changed, the change in the coefficient of dynamic damping is not overgreat. Since, furthermore, the values of $\left|k_{1}\right|$ given above do not differ much from the value shown in the previous paper, we shall use the previous results throughout in subsequent calculations.

\section{Damping Resistance in the Rolling of a Ship in Motion-ahead.}

The linear velocity in the rolling of a ship does not greatly exceed that in the vibration of the same ship. If it is possible to fit our experimental result from the 
vibration of a small plate to such a case as that of rolling, then the experimental result in question should also be applicable to the case of the vibration of a fullsizcd ship.

The equation of rolling motion of a ship may be expressed in the form

$$
I \ddot{\theta}+M m g \theta+\left\{\left|k_{0}\right|+\left|k_{1}\right| V\right\} \dot{\Phi} \dot{\theta}=0
$$

where $I, M, m, g, V$ are the mass moment inertia of the ship about the axis of rolling, the mass of the ship, the metacentric height, the acceleration due to gravity, and the ship's speed respectively. For a ship of rectangular cross-section, the value of $\Phi$ is

$$
\Phi=\alpha\left\{\frac{B^{3} L_{1}}{12}+\frac{2\left(d_{1}^{3}+d_{2}^{3}\right) L_{2}}{3}\right\}+4 \beta A R_{1}^{2}
$$

in which $B$ is the breadth of the flat bottom part, $L_{1}$ the length of the same part; $d_{1}, d_{2}$ are the depths of immersion of the wall-sided part above and below the level surface through the rolling axis; $L_{2}$ is the length of the same part, $A$ the arca of the outer or inner surface of every bilge keel, and $R_{1}$ the distance of the bilge keel from the rolling axis.

In the case of a rounded form of hull, $\Phi$ in (9) can be put in the form

$$
\Phi=4 \beta A R_{1}^{2} \text {. }
$$

Even in this case, the whole area of the bilge keel is not so effective as in the case of our model experiments, namely, the case of a plate vibrating between two side walls of the circulation tank. From this consideration, we shall take $\beta \approx 1 / 2$.

With a view to comparing our results with those of the "Revenge" experiments, we shall now use the data in White's paper ${ }^{(10)}$. The fourth rolling experiment of H.M.S. "Revenge" was conducted on February 13, 1895. The condition of this ship then was as follows: mean draught $27^{\prime} 11^{1 \prime \prime}$, displacement 14,620 tons, metacentric height $3 \cdot 86^{\prime}$, mean period of single (half) swing $7 \cdot 75 \mathrm{sec}\left(=T_{1}\right)$, weight of coal on board 1,782 tons, number of men for exciting free rolling 370 , every bilge keel $200^{\prime}$ long $3^{\prime}$ deep, distance of every bilge keel from the centre of gravity $40_{*}^{1 \prime}$. The midship of the same ship was fairly rounded, the effect of the wall and the bottom on the damping of rolling being thus neglected.

From the foregoing data, we have

$$
\begin{aligned}
I & =T_{1}{ }^{2} M g \mathrm{~m} / \pi^{2}=7 \cdot 75^{2} \cdot 1 \cdot 46.10^{10} \cdot 980.117 / \pi^{2} \\
& =10 \cdot 17.10^{15} \text { gr. mass. } \mathrm{cm}^{2}, \\
\Phi & =4 \beta A R_{1}^{2}=4.0 \cdot 5.5 \cdot 56.10^{5} \cdot 1219^{2}=1 \cdot 65.10^{12} \mathrm{~cm}^{4},
\end{aligned}
$$

(10) Sir W. White, loc. cit. (4). 
so that the damping coefficient of rolling due to dynamic damping alone is

$$
\begin{aligned}
K_{1} & =\frac{\Phi\left|k_{1}\right| \mathrm{V}}{2 I}=\frac{1 \cdot 65.10^{12} \cdot 0 \cdot 358 \mathrm{~V}}{2.10 \cdot 17.10^{15}} \\
& =\frac{0.0290 \mathrm{~V}}{10^{3}} \mathrm{sec}^{-1}, \quad(V \text { in } \mathrm{cm} / \mathrm{sec})
\end{aligned}
$$

from which the damping coefficients of rolling at $V=10 \mathrm{knots}(=514.9 \mathrm{~cm} / \mathrm{sec})$ and 12 knots $(=617 \mathrm{~cm} / \mathrm{sec})$ become

$$
K_{1}=0 \cdot 0149 \mathrm{sec}^{-1}, \quad K_{1}=0 \cdot 0179 \mathrm{sec}^{-1},
$$

respectively.

\section{Comparison of the Above Results with the Data of the "Revenge" Rolling Experiments.}

White's paper gave the data of free rolling of the "Revenge" in the condition shown in the preceding section. Starting from the initial angle of roll, namely, 5

\begin{tabular}{|c|c|c|c|}
\hline Case & (A) & (B) & (C) \\
\hline Ship speed & Nil & 10 knots & 12 knots \\
\hline After 4 (half) swings & 2.95 deg. & $2 \cdot 35 \mathrm{deg}$. & $2.2 \mathrm{deg}$ \\
\hline$\ldots \ldots 8 \ldots \ldots \ldots \ldots$ & $1.95 \ldots$ & $1.19 \ldots$ & $1.05 \ldots$ \\
\hline .......12.......... & $1.45 \ldots$ & $0.55 \ldots$ & $0.45 \ldots$ \\
\hline$\ldots \ldots 16 \ldots \ldots \ldots \ldots$ & $1.15 \ldots$ & $0.20 \ldots$ & $0.25 \ldots$ \\
\hline
\end{tabular}
degrees, the inclining angles after successive finite numbers of swings for various ship speeds became

It is possible to evaluate from this table the damping coefficient of every case. Let the damping coefficients in the respective cases be $K_{0}+K_{1} ; K_{0}, K_{1}$ being the parts contributed from the damping in still water and dynamic damping respectively. The mean values of the damping in the three cases then become

$\begin{array}{lll}\text { Case (A) } & \text { Case (B) } & \text { Case (C) } \\ \text { No speed } & 10 \text { knots } & 12 \text { knots } \\ K_{0}=0.0142 \mathrm{sec}^{-1} & K_{0}+K_{1}=0.0244 \mathrm{sec}^{-1} & K_{0}+K_{1}=0.0258 \mathrm{sec}^{-1}\end{array}$

If the equation of rolling motion could be put in the same form as in (8), the form of the additive type, $K_{0}+K_{1}$, of the damping coefficient of the rolling, is reasonable. From the above result, it is now possible to assume that the coefficients of dynamic damping in rolling of the "Revenge" at 10 knots and 12 knots were

$$
K_{1}=0 \cdot 0102 \mathrm{sec}^{-1}, \quad K_{1}=0 \cdot 0114 \mathrm{sec}^{-1},
$$

respectively. 
Comparing (12) with (13), it will be seen that the value of the dynamic damping coefficient of rolling of the "Revenge" that was predicted from the result of our previous model experiments is in the same order of magnitude as the one that is deduced directly from the data gained in the actual rolling experiments of the same ship. Even if it is assumed that $\beta=$ unity, in lieu of $1 / 2$, the estimated value of $K_{1}$ is not far from that in actual experiments, not at any rate, in the order of its magnitude. If, furthermore, the value of $\beta$ were assumed to be somewhat less than $1 / 2$, it would be possible to get the estimated value of $K_{1}$ almost equal to its experimental value, although such an agreement in the two values in $K_{1}$ is of no theoretical importance.

At all events, that the value of the dynamic damping coefficient as predicted from an idealized model experiment should have the same order of magnitude as the observed value in the rolling of an actual ship, is interesting. It now seems that the value of the dynamic damping coefficient found in model experiments is applicable to the vibration damping of a ship in her motion-ahead with somewhat less error and, furthermore, to the case of damping in the pitching of the same moving ship.

\section{Damping Resistance in the Pitching of a Ship in Motion-ahead.}

It is an actually observable fact that the pitching of a ship in her motionahead condition is damped more quickly than in her stand-still condition.

Taking damping in its dynamical sense only, the equation of pitching motion of a ship is expressed by

$$
I^{\prime} \ddot{\phi}+M m^{\prime} g \phi+\left|k_{1}\right| V \Psi \dot{\phi}=0,
$$

where $I^{\prime}, m^{\prime}$ are the mass moments of inertia of the ship about her pitching axis and the longitudinal metacentric height respectively. If $l_{1}+l_{2}$ be the length of the flat bottom part with varying breadth $b ; \Psi$ can be put $\gamma \int_{-l_{1}}^{l_{2}} b x^{2} d x, \gamma$ being a constant less than unity. If $b$ does not vary along the ship's length and $\gamma=1$, we get $\Psi=b\left(l_{1}^{3}+l_{2}^{3}\right) / 3$.

Although the values of $I^{\prime}, m^{\prime}$ in the case of the "Revenge" are not known, in order to get the approximate damping coefficient, we write

$$
\begin{aligned}
b & =70^{\prime}(=212 \mathrm{~cm}), \quad l_{1}=l_{2}=100^{\prime}(=3,030 \mathrm{~cm}), \\
I^{\prime} & =14,600^{T} .50^{\prime 2}=0 \cdot 337.10^{17} \text { gr.mass. } \mathrm{cm}^{2} .
\end{aligned}
$$

Then 


$$
\left|k_{1}\right| \Psi=\left|k_{1}\right| \frac{b}{3}\left(l_{1}^{3}+l_{2}^{3}\right)=14 \cdot 0.10^{12} \text { gr.mass. cm, }
$$

$\left|k_{1}\right|$ being 0.358 gr.mass $/ \mathrm{cm}^{3}$, so that the damping coefficient of pitching due to dynamic damping alone is

$$
K_{1}=\frac{\Psi\left|k_{1}\right| V}{2 I^{\prime}}=\frac{14 \cdot 0.10^{12} \mathrm{~V}}{2.0 \cdot 337.10^{17}} \mathrm{sec}^{-1}, \quad(V \text { in } \mathrm{cm} / \mathrm{sec})
$$

from which the damping cofficients of pitching at $V=10$ knots and 12 knots become

$$
K_{1}=0 \cdot 107 \mathrm{sec}^{-1}, \quad K_{1}=0 \cdot 128 \mathrm{sec}^{-1},
$$

respectively.

Comparing (16) with (12) it will be seen that the dynamic damping coefficient in pitching motion is much larger than that in rolling motion. It is obvious that the pitching motion of an actual ship in motion-ahead in a calm sea is generally very quickly damped,-a fact agreeing well with our present theory. The condition that the pitching of an actual ship is rather marked in motion-ahead in rough weather merely results from the excitation due to large waves, but not from the smallness of the dynamic damping.

\section{Damping Resistance in the Vibration of a Ship in Motion-ahead.}

This problem was dealt with in the previous paper and also in Section 2 of the present paper. But, for ascertaining its nature more clearly, we shall now show the treatment of the problem and exemplify it by using the data of the "Revenge."

If we assume that the ship is in the form of a uniform bar, the equation of the flexural vibratory motion is

$$
\rho A \frac{\partial^{2} y}{\partial t^{2}}+\left\{\left|k_{0}\right|+\left|k_{1}\right| V\right\} b \frac{\partial y}{\partial t}+E I \frac{\partial^{4} y}{\partial x^{4}}=0 .
$$

Putting $y=Y T$, the equation transforms to the following pair of expressions

$$
\begin{gathered}
\rho A \frac{d^{2} I}{d t^{2}}+\left\{\left|k_{0}\right|+k_{1} \mid V\right\} b \frac{d T}{d t}+n^{2} T=0, \\
E I \frac{a^{4} Y}{d x^{4}}=n^{2} Y .
\end{gathered}
$$

From $\left(3^{\prime}\right)$ the damping coefficient due to dynamic damping alone assumes the form

$$
K_{1}=\frac{b}{2 \rho A}\left|k_{1}\right| V,
$$


where $b$ is the breadth of the bar and $\rho A$ the mass per unit length of the same bar. If, on the other hand, $M$ be the mass of the ship, the above damping coefficient may be replaced by

$$
K_{1}=\frac{b_{1} L_{1}}{2 M}\left|k_{1}\right| V
$$

where $L_{1}, b_{1}$ are the effective length and breadth, along both of which the dynamic damping force of water is imparted.

Let us assume that

$$
\begin{aligned}
& L_{1}=200^{\prime}(=6,060 \mathrm{~cm}), \quad b_{1}=70^{\prime}(=2,120 \mathrm{~cm}), \\
& M=14,600 \text { tons }=1 \cdot 46.10^{10} \text { gr.mass, }\left|k_{1}\right|=0 \cdot 358 \mathrm{gr} . \mathrm{mass} / \mathrm{cm}^{3},
\end{aligned}
$$

then

$$
K_{1}=\frac{1 \cdot 57}{10^{4}} V \mathrm{sec}^{-1}, \quad(V \mathrm{in} \mathrm{cm} / \mathrm{sec})
$$

\begin{tabular}{|c|c|c|c|}
\hline$V(\mathrm{kts})=1.94$ & $9 \cdot 7$ & 10 & 12 \\
\hline${ }_{1}\left(\sec ^{-1}\right)=0.0157$ & 0.0786 & 0.0810 & 0.0973 \\
\hline
\end{tabular}

from which it is possible to guess the damping coefficient of vibration due to dynamic damping alone, some examples being shown below

As already shown, the damping coefficient $K_{0}$ of the ship's vibration in her standstill condition is nearly equal to that due to dynamic damping at her speed of 6 or 7 knots. It should be added that in this case, too, the actual damping coefficient of the vibration is $K_{0}+K_{1}$.

Since our present result shows the damping force only qualitatively, the value $\left|k_{1}\right|=0.358 \mathrm{gr} . \mathrm{mass} / \mathrm{cm}^{3}$ therefore represents its coefficient in the order of magnitude.

Since vibrational forces due to the engines or propellers usually increase as the square of the shaft revolution, even if the dynamic damping be augmented with the ship's speed, the amplitudes of the ship's vibrations should become larger and larger with increase in speed. Apart from the dynamic damping, there is, besides, evidence that, beyond the resonance condition, the vibration amplitude in forced oscillation tends to decrease as the result of energy conditions, whence, even should the vibrational force increase as the square of the ship's speed, the vibration amplitude at any higher frequency is likely to remain constant apart from the effect of damping resistance, the vibrational acceleration, however, increasing as the square of the ship's speed. It follows then that when the vibration is resisted by the dynamic damping force, the amplitude of the same vibration tends to decrease with 
increase in ship speed, the acceleration, on the other hand, quickly increasing with the same increase.

\section{Applicability of the Results of Model Experiments to Problems connected with the Dynamic Damping of Ship Vibrations, as Confirmed by the Resistance to Ship's Rolling.}

In the previous paper, from the results of model experiments in a circulation water tank, the dynamic damping of the vibrations of a ship in her motion-ahead was predicted. Although, from the nature of things, it is likely that the experimental results could be availed of in the case of the vibration damping of an actual vessel, since the vibration amplitudes of any ship apparently increase with ship speed, some doubt has remained as to whether or not the damping conditions in a full-sized ship would obey the law that we have formulated. Although the condition that the amplitudes generally increase with speed, can be explained by the vibrational forces increasing with shaft revolution, the statement that the order of magnitude of the damping resistance can be applied to any other case, has not yet been confirmed.

On the other hand, the results of rolling experiments with the "Revenge" that were conducted about fifty years ago, have supplied us with a good doal of data for confirming the applicability of the damping coefficient that we have deduced.

Notwithstanding that the vibrational condition in our experiments of a model plate in a circulation water tank differed entirely from the conditions that attended the rolling experiments of the "Revenge" in oscillatory frequency as well as in displacement velocity, the predicted damping coefficient of rolling of the "Revenge" fairly agrees with the same coefficient that had been actually observed in the same ship. It is then possible for us to conclude that the data of our model experiments immediately apply to the vibrations of an actual ship whose frequencies and amplitudes lie within the range of the vibrating model plate in our experiments. In extending our investigation to the case of the pitching motion of a ship, the reason that the pitching of a ship in motion-ahead condition in a calm sea is lamped more quickly than in stand-still condition, has been ascertained.

\section{Concluding Remarks.}

In the present paper the treatment of the problem is entirely based on the results of model experiments, partly shown in our previous paper and partly in the 
present one, the validity of the problem being confirmed by the results of rolling experiments with H.M.S. "Revenge" that were made about fifty years ago. Since, as a matter of fact, the problem is merely qualitative, it is impossible for us to discuss at present the precise values of the damping coefficient in question. It is to be hoped that some investigator having access to any of the usual experimental water tanks will conduct experiments relating to the present problem.

In the present investigation, the author received much kind advice from Professir Y. Hiraga, President of the Tokyo Imperial University, to whom he wishes to express his sincerest thank. He also wish to express his warmest thank to the Council of the Kondô Memorial Marine Foundation for aid given to a series of investigations, of which this study is a part.

（本論文に對して講演會の後日に次の written discussion が提出されたので之を揭载する）

\section{妹澤博士の論文に就ての私見}

\section{正員渡 邊 惠 弘}

平板が流水中で振動する際の水より働く hydrodynamic damping 飞關する妹澤博士の研究は、我 我に取つては非常に興味のある有益なもので、非常に面白く拜見しました。私は當日同博士の講演を

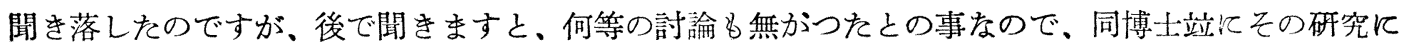
敬意を表する意味で少しく私見を述べせせ頂き度いと思ひます。唯私の此處で述べるのは動搖に關 する範圍內に於てであります。

妹澤博士は其の賽驗結果を船の橫及縱動搖に適用して bilge keel とょる減変力を計算して居られ ます。此中横動摇に對する前進速度の影響に就ては、實船及模型を以てする色々の窞驗があります が、縱動摇に關しては見當りません。それで橫動搖に關して、少しく感想を述べ度いと思ひます。 從來の橫動搖と前進速度との關係の實船による實驗は妹澤博士の言及して居る “Revenge ” の外に Bertin が 9 ton ばかりの小さい电船 “Navette”にて實驗して居り、最近では “Conte di Savoia” (Sperry の Gyro を裝置し B. K. はなし) に就て試驗され、又極く最近の報告に依れば和䒽で、特 殊の B.K. をつけた驅逐艦で試驗して居り、我國の元良式 fin を附けた睦丸の試驗も此中に數へられ ませう。之等の結果によれば何れも前進速度のために、減衰力峙著しく增加して居ります。然ると此 處に面白い事は “Conte di Savoia” は B.K. が無いのにも拘ら亦前進速度があると減衰力が非常に 大となつて居る事で、之はその模型試驗に於ても現れて居ます。(T.S.N.A.M.E. 1936)。此の事に就 ては R. E. Froude が或る驅逐艦の實驗の報告に於て、B.K. の無い船が $17 \mathrm{kt}$ の前進速度を有する 
際の extinction は、同じ船が B.K. をつけて前進速度を持を娃の夫れの約 2 . 倍になると言つて居 ると云ふ事を Payne が述べて居ります(T.I.N.A. 1924)。Payne は此論交の中で前進速度の影響に 關する模型試驗の結果を報告して居るのですが、矢張り B.K. を附けない船が $20 \mathrm{kt}$ の速度では、速 度なしの時の 4 倍の extinction があると言つて居ます。之之關係ある事柄として私の處で行つた實 驗で、船に橫動摇を與へながら前進速度を與へると、非常に大き週期的な yawing moment が現れ、此 moment は速度が大きい程大となる事が確められました。 speed length ratio が 0.80 附近の速度で $5^{\circ}$ 位の振福の橫動搖の際々現れる此 yawing moment の最大值は舵角 $5^{\circ}$ 位で初めて balance される 程度のものであります。是岄明に橫動搖と速度との爲めに起る船侧に働くhydrodynamical pressure によるもので、橫動摇を止める方向に働きます。之等つ事から、船體それ自身が前身速度に低つて、 橫動摇を damp する可なり大きい力を有する事が明かである樣江思はれます。

B.K. を有する船が前進速度を有する場合飞就ては前記の Payne と R. Legendre (B.A.T.M.A. 1932) が實驗して居ります。Payne は其の實驗より、B.K. がある場合は前進速度は小さい動搖角の時以外 に於ては damping には影響快無いと結論して居ますが、實驗の曲線を見ると、此持の damping が 大きんので速度の影響分はつきりして居らない丈けで、速度に依つて damping の燴加する傾向のあ る事は看取されます。Legendre の實驗では 4.9 米の模型で 1米/秒の速度迄は、或る時悑遮に依 つて却つて damping が減る事もあるが、1米/秒 以上では菂加すると云ふ結果が現れて居ますが、 此實驗で速度の速い時は實驗の error が入つて居るのではないかと云ふ疑が持たれる故（側壁より の反射波の爲め) 絕對の信賴㳉置き難い樣です。

果して然らば前進速度つ爲めに B.K.の作用がぞれだけ增加するかと云ふ事は、以上の結果だけで は判明しません。妹澤博士の實驗にも現れて居る樣て、板が流水中で振動すれば、此板は飛行機の翼

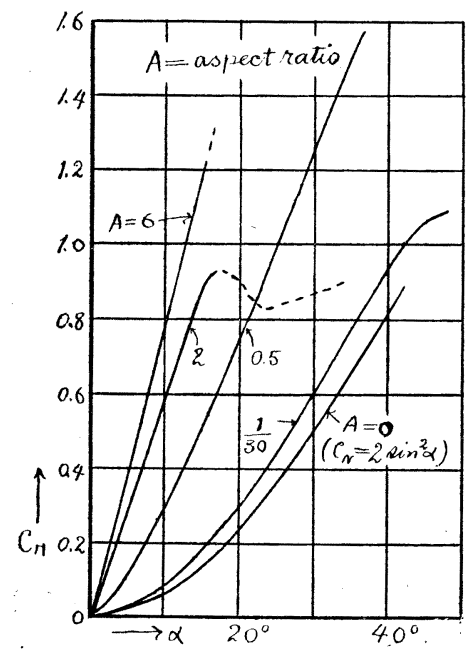
の樣な作用をなして之に働く力は水の速度と共に堆加する事は 明かで、故淺犲功敎授も元良式 fin の理淪を此考へから研究し て居ります。然しながら普通の船に取付けられて居る B.K. の樣泀、高さに比して長さの方向に長い即ち aspect ratio の 非常に小さん板に對して、aspect ratio の小さい時之同樣浪考

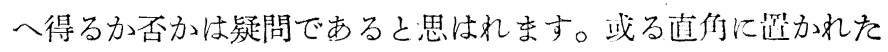
板に働く normal force coef. $C_{N^{\prime}}=$ normal force $\left./ \dot{2} \rho F U^{2}\right)$ と 迎角 $\alpha$ 之の關係は aspect ratio が大きい時は略々1次の關係

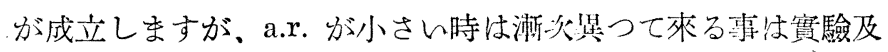
理論 (Bollay： Z.A.M.M. Feb. 1939) からも示され大體圖の樣 になります。

板が振動しない時の此結果を、应動板に適用するには或る 
:correction が必要とは思ひますが、a.r.の大きい時に此補正なしで近似的に applyされる樣に a.r. の小さい場合に就いても同樣の近似老許す事にしませう。上圖で面白い事は a.r.が小さい時は $45^{\circ}$

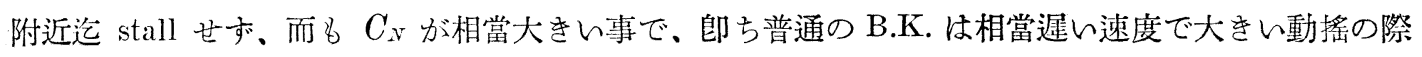
8 stall せ军江有效に働く事が出來ます。

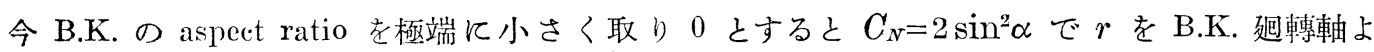
りの距離、白を動摇角速度とすれば $\sin \alpha=\frac{r \dot{\theta}}{U}\left(U=\sqrt{V^{2}+r^{2} \dot{\theta}^{2}}\right)$ るる故 B.K. に働く normal force は $\rho r^{2} \theta^{2} F$ ( $F$ は B.K. の面積) となり、是壮前進速度がない時に B.K. に㗢く力と同じとなり（此時 \& $C \rho r^{2} \theta^{2} F$ で $C \fallingdotseq 1$ である) 而も速度に無關係と云ふ結果になります。此考へ方が果して正しい かぼうか壮實驗して見なければわかりませんが、是丈けから見れば普通の proportion の B.K. は前 進速度に依つて像期される程 (a.r. の小さい有限値の時は $V$ 亿比例する項が現れるが小さい故)減衰 力の增加を來さない柡に思はれます。此外 Bryan の指摘した如き B.K. と船體との干涉による damping effect が前進速度によつてどう變るかと云ふ樣教事名りますが、是壮はつきり分らない が左樣增加すると壮思はれません。

勿渝林澤博-1:の實驗の樣な aspect ratio の比較的大きい板を B.K. K使へば元良式 fin の如く前 進速度の影響忛大きく現れる事は明かで、殊飞速度が大なる程影響が大となる事は同博士の analysis から明かであります。最近和蘭で實驗されたものの如く〈Jr. W. Rosingh : Shipb. \& Ship. R. Oct. 27, 1938) B.K.を舆さの力向に短く切つて並べたa.r.の大きい板では前進速度の影響が强く現れる 事は上の事よりかかります。前述の Legencre が知長り同じ樣に B.K. 竞短く切つて實驗しました

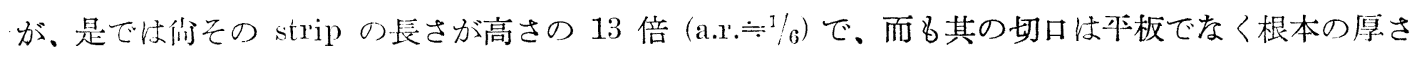
が高さの ${ }^{1 / 4}$ 女ある楔形のものを使つてある爲め、普通の B.K. に比較して充分有效の働きを示さな かつたのであります。

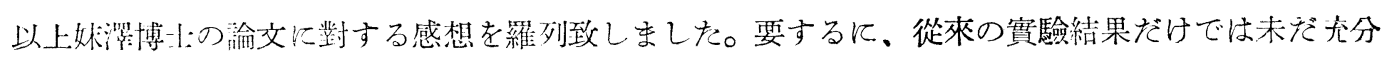

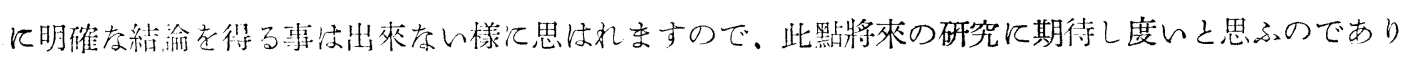
ます。

\section{渡邊博士の御急見に對する御禮}

正真妹 滥 克 惟

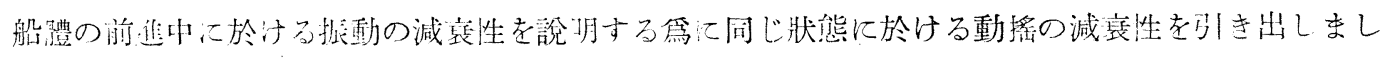

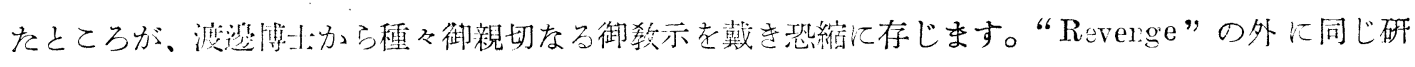

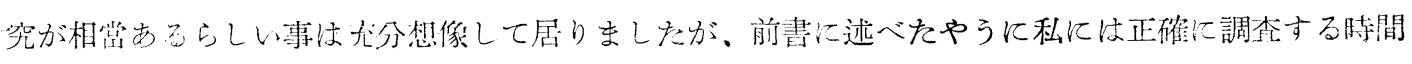

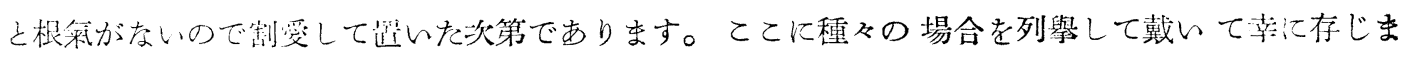


す。

B.K.のみを問題になさつたやうですが、B.K. がなくても船底、船側が適當索形であれば、同樣な 作用のある事は本交中に述べを通りであります。“Revenge”の横搖には其の船底の形から B.K. の みを取りました。をだ B.K. や船底の aspect ratio が小さくなると板面に働く垂直力が減少する事 は勿論であり、そのをめに私の研究では飛行機の翼などよりも相當小なる a.r. の板の實驗を致しま した。之でも船の場合よりは可なり隔つて居りますが、本文に述べたやうに、“Revenge”の結果に 數分の一と云ふ factor を掛けると、結果が相當よく合ひました。從つて之等の實驗結果を否定する 譯には行かぬと思ひます。

佾餘計な事ですが、振動の分析に於て重遖力 $=(\rho / 2) C_{N} V^{2} F$ と書き而も a.r.=0 のときの Bollay の 式 $C_{N}=2 \sin ^{2} \alpha$ の中の $\sin \alpha$ の值として直ちに $\sin \alpha=r \dot{\theta} / \sqrt{V^{2}+r^{2} \dot{\theta}^{2}}$ としてしまふのは如何なもの でせうか。私をして書かしめれば、振動に於ける垂直力の減衰性の部分は當然 $(\rho / 2)\left(\partial C_{N} / \partial \alpha\right) \alpha_{1} V^{2} F$ (但し $\left.\alpha_{1}=r \dot{\theta} / V\right)$ ，即ち $\rho \sin 2 \alpha r \dot{\theta} V F$ と致します。之は勿論小振動型の式であり、且つ流體力學的 にも第1近似の形式であります。乙の場合に $\alpha=0$ の位笾では減衰力が零となりますが、それ以外の 迎角附近の振動では $V$ に比例する減奎力が御座います。更に實船に於て船底や船倒の a.r. は必しも 零に近いと云はれませんし、B.K.でもその有效部分は a.r. $\rightarrow 0$ と置く譯には行か好故、 $\alpha=0$ の附近 でも $\partial C_{N} / \partial \alpha \neq 0$ であると考へられます。

鬼も角も私の振動減変性の問題には “Revenge” の結果が可なり役立ちましたつもりですけれど も、一般の動摇の問題については、終始動摇の御研究を御やりになつてる、渡邊博士かどなたかに模 型賽驗でもよいから上述の減変性の有無を是非實地によく確めて戴き度いと思ひます。以上大變御親 切なる御意見への御禮の序に一二の點を附加へた次第であります。 